\title{
EFIKASI ASAP CAIR DARI KAYU LABAN (VITEX PUBESCENS) TERHADAP RAYAP COPTOTERMES CURVIGNATHUS
}

\author{
HA Oramahi, Purwati, Sofian Zainal, Iskandar, Idham, Farah Diba, \& Wahdina \\ Fakultas Kehutanan, Universitas Tanjungpura \\ Jl. Imam Bonjol Pontianak \\ E-mail: oramahi_stp@yahoo.com
}

\begin{abstract}
Efficacy of liquid smoke from laban wood (Vitex pubescens) against Coptotermes curvignathus. Antitermitic activities of liquid smoke produced from Vitex pubescens against $C$. curvignathus was evaluated in this study. This research was conducted in two steps, i.e. pyrolisis of liquid smoke and efficacy test of liquid smoke as antitermite. Three kinds of liquid smoke were produced at three different pyrolysis temperatures, i.e. $350^{\circ} \mathrm{C}, 400^{\circ} \mathrm{C}$ and $450^{\circ} \mathrm{C}$. Termiticidal activity was evaluated by a nochoice test. The research indicates that concentration of liquid smoke and pyrolysis temperatures significantly affected termite mortality and mass losses of the filter paper. The relationship between the concentration of liquid smoke (X) and termite mortality $(\mathrm{Y})$ at $350^{\circ} \mathrm{C}, 400^{\circ} \mathrm{C}$, and $450^{\circ} \mathrm{C}$ were $\mathrm{Y}=31,4+11,76 \mathrm{X},\left(\mathrm{r}^{2}=0,60\right), \mathrm{Y}=30+11,86 \mathrm{X}\left(\mathrm{r}^{2}=0,59\right)$, and $\mathrm{Y}=26,66$ $+7,6 \mathrm{X}\left(\mathrm{r}^{2}=0,429\right)$. The relationship between concentration of liquid smoke $(\mathrm{X})$ and mass losses $(\mathrm{Y})$ at $350^{\circ} \mathrm{C}, 400{ }^{\circ} \mathrm{C}$, and 450 ${ }^{\circ} \mathrm{C}$ were $\mathrm{Y}=85,12-3,188 \mathrm{X}\left(\mathrm{r}^{2}=0,723\right), \mathrm{Y}=88,06-3,435 \mathrm{X}+\left(\mathrm{r}^{2}=0,953\right)$ and $\mathrm{Y}=91,56-3,867 \mathrm{X}\left(\mathrm{r}^{2}=0,886\right)$.
\end{abstract}

Key words: antitermite activity, liquid smoke, Vitex pubescens

\begin{abstract}
ABSTRAK
Efikasi asap cair dari kayu laban (Vitex pubescens) terhadap Rayap Coptotermes curvignathus. Pengujian antirayap asap cair yang diperoleh dari kayu laban terhadap C. curvignathus telah dilakukan. Pengujian ini bertujuan mengevaluasi kemampuan asap cair sebagai antirayap secara in vitro. Tahap-tahap penelitian terdiri atas pembuatan asap cair dari kayu laban dan aplikasinya terhadap rayap C. curvignathus. Tiga jenis asap cair diperoleh dengan cara pirolisis pada suhu $350^{\circ} \mathrm{C}, 400^{\circ} \mathrm{C}$ dan $450^{\circ} \mathrm{C}$. Aplikasi asap cair tehadap rayap menggunakan metode uji makan tunggal. Hasil pengujian menunjukkan bahwa konsentrasi asap cair dan suhu pirolisis berpengaruh nyata terhadap mortalitas rayap dan kehilangan berat kertas saring $(p<0,05)$. Hubungan antara konsentrasi asap cair $(\mathrm{X})$ dan mortalitas rayap $(\mathrm{Y})$ pada suhu pirolisis asap cair $350^{\circ} \mathrm{C}, 400^{\circ} \mathrm{C}$, dan $450^{\circ} \mathrm{C}$ berturut-turut adalah $\mathrm{Y}=31,4+11,76 \mathrm{X},\left(\mathrm{r}^{2}=0,60\right), \mathrm{Y}=30+11,86 \mathrm{X}\left(\mathrm{r}^{2}=0,59\right)$, dan $\mathrm{Y}=26,66+7,6 \mathrm{X}\left(\mathrm{r}^{2}=0,429\right)$. Hubungan antara konsentrasi asap cair $(\mathrm{X})$ dan kehilangan bobot kertas saring $(\mathrm{Y})$ pada suhu pirolisis asap cair $350^{\circ} \mathrm{C}, 400{ }^{\circ} \mathrm{C}$, dan 450 ${ }^{\circ} \mathrm{C}$ berturut-turut adalah $\mathrm{Y}=85,12-3,188 \mathrm{X}\left(\mathrm{r}^{2}=0,723\right), \mathrm{Y}=88,06-3,435 \mathrm{X}+\left(\mathrm{r}^{2}=0,953\right)$ dan $\mathrm{Y}=91,56-3,867 \mathrm{X}\left(\mathrm{r}^{2}=0,886\right)$.
\end{abstract}

Kata kunci: aktivitas antirayap, asap cair, Vitex pubescens

\section{PENDAHULUAN}

Rayap menyebabkan kerusakan produk hasil kehutanan seperti bangunan dan perabot rumah tangga yang terbuat dari kayu (Meyer, 2005; Verma et al., 2009; Ghaly \& Edwards, 2011). Rayap juga merupakan salah satu organisme penting sebagai hama pada tanaman perkebunan dan tanaman hutan (Jones \& Prasetyo, 2002; Calderon \& Constantino, 2007; Jasmi \& Ahmad, 2011). Jasmi \& Ahmad (2011) melaporkan bahwa sekitar 21,5\% tanaman jenis Araucaria diserang oleh rayap Coptotermes curvignathus, Schedorhinotermes medioobscurus, dan Odontotermes sarawakensis. Di antara ketiga jenis rayap tersebut, $C$. curvignathus merupakan rayap yang paling dominan menyerang tanaman Araucaria yaitu sebesar $74 \%$. Kerugian akibat serangan rayap di Amerika Serikat sebesar 800 juta dollar per tahun (Meyer, 2005) sementara di Jakarta kerugian akibat serangan rayap $C$. curvignathus di kawasan pemukiman sebesar 500 juta rupiah per tahun (Nandika et al., 2003).

Pengendalian rayap dengan bahan kimia sudah lama dilakukan, namun dampak bagi lingkungan dan kesehatan manusia sangat besar. Penggunaan bahan kimia juga dapat menyebabkan kematian organisme bukan sasaran. Oleh karena itu, perlu dicari alternatif pengendalian rayap dengan menggunakan bahan yang ramah lingkungan seperti penggunaan asap cair. Asap cair merupakan produk hasil pembakaran kayu atau 
biomassa dengan cara pirolisis menggunakan suhu tinggi tanpa udara (Lee et al., 2011). Kayu sebagai komponen bahan bakar umumnya tersusun atas komponen utama yaitu selulosa, hemiselulosa, dan lignin (Maga, 1987). Produksi asap cair merupakan hasil pembakaran kayu yang tidak sempurna yang melibatkan dekomposisi, reaksi oksidasi, polimerisasi, dan kondensasi (Girard, 1992).

Asap cair yang diperoleh dari pirolisis serbuk kayu (mebel) mengandung komponen kimia yang sangat kompleks, antara lain asam asetat, pirazin, siklopentanon, furanmetanol, 2-metil-2siklopenten-1-on, fenol, 2metilfenol, asam benzoat, 2-metoksifenol. 2-metoksi-4metilfenol, dan 2,6-dimetoksifenol (Heo et al., 2011), Oleh karena itu asap cair dapat berfungsi sebagai antijamur (Kartal et al., 2004; Mohan et al., 2008; Okutucu et al., 2011), antibakteri (Darmadji, 1997; Karseno et al., 2001; Bedmutha et al., 2011; Lee et al., 2011), dan antirayap (Yatagai et al., 2002; Lee et al., 2010; Oramahi \& Yoshimura, 2013). Mohan et al. (2008) mengungkapkan bahwa asap cair dari kayu pinus dan kayu oak mampu menghambat pertumbuhan jamur Gloeophyllum trabeum dan Trametes versicolor. Bedmutha et al. (2011) menemukan bahwa asap cair mampu menghambat partumbuhan bakteri Streptomyces scabies dan Clavibacter michiganensis subsp. michiganensis. Oramahi \& Yoshimura (2013) menyatakan bahwa asap cair dari kayu laban (Vitex pubescens) hasil pirolisis pada suhu $450{ }^{\circ} \mathrm{C}$ berperan sebagai antirayap terhadap rayap Reticulitermes speratus dan $C$. formosanus.

Komponen penyusun asap cair sangat dipengaruhi oleh berbagai faktor antara lain suhu pirolisis dan jenis bahan (jenis kayu). Heo et al. (2011) meneliti asap cair yang hasil pirolisis serbuk kayu (mebel) pada suhu pirolisis $400{ }^{\circ} \mathrm{C}, 450{ }^{\circ} \mathrm{C}, 500{ }^{\circ} \mathrm{C}$, dan $550{ }^{\circ} \mathrm{C}$. Hasil penelitian menemukan bahwa kandungan asam asetat meningkat secara cepat hingga suhu $500{ }^{\circ} \mathrm{C}$, dan turunan fenol menurun seiring dengan penurunan suhu pirolisis. Perbedaan komponen penyusun asap cair terutama kandungan asam asetat dan fenol diduga sangat memengaruhi kemampuan sebagai antirayap.

Berdasarkan hal tersebut, perlu dilakukan penelitian pembuatan asap cair dari kayu laban pada suhu pirolisis $350{ }^{\circ} \mathrm{C}, 400{ }^{\circ} \mathrm{C}$, dan $450{ }^{\circ} \mathrm{C}$ serta mengevaluasi sifat antirayap asap cair yang diperoleh terhadap C. curvignathus. C. curvignathus merupakan jenis rayap yang banyak merusak khususnya di Indonesia baik pada tanaman perkebunan, tanaman kehutanan dan produk hasil hutan kayu serta perabot rumah tangga yang terbuat dari kayu. Nilai kerugian pada tanaman perkebunan kelapa sawit akibat serangan rayap $C$. curvignathus mencapai 50 juta rupiah per hektar (Nandika et al., 2003).

\section{METODE PENELITIAN}

Tempat dan Waktu. Persiapan bahan baku kayu laban dilakukan di Laboratorium Wood Workshop, pengujian asap cair terhadap rayap $C$. curvignathus dilakukan di Laboratorium Teknologi Kayu, Fakultas Kehutanan, Universitas Tanjungpura, Pontianak. Pirolisis asap cair kayu laban dilakukan di Laboratorium Rekayasa Fakultas Teknologi Pertanian, Universitas Gadjah Mada, Yogyakarta. Penelitian dilakukan dari September sampai dengan Nopember 2012.

Pembuatan Asap Cair. Pembuatan asap cair dengan menggunakan cara pirolisis (Tranggono et al., 1996; Darmadji et al., 2000; Oramahi \& Yoshimura, 2013). Bahan baku kayu laban terlebih dulu dikeringkan dengan kadar air sekitar 15\%, lalu dihaluskan dan diayak. Asap cair dibuat dengan memasukkan bahan ke dalam reaktor kemudian ditutup dan rangkaian kondensor dipasang, dapur pemanas dihidupkan dengan suhu $350{ }^{\circ} \mathrm{C}, 400$ ${ }^{\circ} \mathrm{C}$, dan $450{ }^{\circ} \mathrm{C}$ dengan waktu pirolisis selama 90 menit. Asap yang keluar dari reaktor disalurkan ke kolom pendingin melalui pipa penyalur, kemudian ke dalam kolom pendingin ini dialirkan air dingin dengan menggunakan pompa. Embunan berupa asap cair ditampung dalam botol, sedangkan asap yang tidak dapat diembunkan dibuang melalui pipa penyalur asap sisa. Rendemen asap cair diperoleh dihitung sebagai \% bobot.

Koleksi Rayap. Rayap diperoleh dari tegakan pohon yang terserang di Arboretum Sylva Universitas Tanjungpura. Rayap yang digunakan adalah $C$. curvignathus dengan ciri-ciri rayap prajurit sebagai berikut: kepala berwarna kuning kecokelatan, bentuk kepala bulat ukuran panjang sedikit lebih besar daripada lebarnya. Mandibel berbentuk seperti arit dan melengkung di ujungnya. Abdomen berwarna putih kekuningan, labrum dan pronotum berwarna kuning pucat. Ciri-ciri rayap kasta pekerja sebagai berikut: tubuhnya berwarna pucat, penebalan yang terjadi pada kutikula cenderung sedikit, merupakan rayap yang mempunyai peranan penting dalam koloni, tecermin dari jumlahnya dalam koloni yang mencapai $80-90 \%$ (Nandika et al., 2003). Pemeliharaan rayap dilakukan di dalam ember yang diberi kayu karet sebagai sumber makanan, lalu ember ditutup dengan plastik hitam untuk menjaga kelembapan. 
Pengujian Asap Cair terhadap Rayap $C$. curvignathus secara In Vitro. Prosedur pengujian pada rayap mengacu pada Kang et al. (1990) dan Ganapaty et al. (2004). Asap cair dari kayu laban sebanyak 0,3 ml diteteskan pada kertas saring Whatman No 1 (diameter $55 \mathrm{~mm}$ ), selanjutnya kertas saring diletakkan di dalam cawan petri. Rayap C. curvignathus sebanyak 50 ekor pekerja dan 5 ekor prajurit diletakkan di dalam cawan petri. Cawan petri kemudian diletakkan dalam ruang inkubasi rayap selama 21 hari. Untuk kontrol kertas saring ditetesi akuades sebanyak $0,3 \mathrm{ml}$. Sebagai perlakuan adalah konsentrasi asap cair $(0 \%, 2,5 \%, 5 \%$, dan 7,5\%) dengan ulangan sebanyak tiga kali. Variabel pengamatan meliputi persentase kematian rayap dan kehilangan bobot kertas saring berdasarkan metode Ohmura et al. (2000) dan Owoyemi et al. (2011) sebagai berikut:

$$
\text { Mortalitas }(\%)=\frac{N_{1}-N_{2}}{N_{1}} \times 100 \%
$$

dengan catatan

$\mathrm{N}_{1}=$ jumlah rayap awal (individu),

$\mathrm{N}_{2}=$ jumlah rayap pada saat akhir pengujian (individu).

Kehilangan bobot kertas saring $(\%)=\frac{B_{1}-B_{2}}{B_{1}} \times 100 \%$

dengan

Kbks= kehilangan bobot kertas saring (\%),

$\mathrm{B}_{1}=$ bobot kertas saring mula-mula $(\mathrm{g})$,

$\mathrm{B}_{2}=$ bobot kertas saring pada saat akhir pengujian $(\mathrm{g})$.

Analisis Data. Analisis regresi linier sederhana digunakan untuk menentukan pengaruh konsentrasi (X) terhadap mortalitas rayap dan kehilangan berat kertas saring $(\mathrm{Y})$. Suhu pirolisis asap cair yang terdiri dari 350 ${ }^{\circ} \mathrm{C}, 400{ }^{\circ} \mathrm{C}$, dan $450{ }^{\circ} \mathrm{C}$ dan konsentrasi asap cair yaitu $0 \%, 2,5 \%, 5 \%$, dan 7,5\%. Masing-masing perlakuan diulang sebanyak tiga kali.

Persamaan regresi sederhana (Montgomery, 1991) sebagai berikut:

$$
Y=b_{0}+b x
$$

dengan catatan

$\mathrm{Y}=$ variabel terikat (mortalitas rayap C. curvignathus,

$\%$ atau kehilangan berat kertas saring, g),

$b_{0}=$ konstanta,

$b=$ koefisien regresi dan

$\mathrm{X}=$ variabel bebas (konsentrasi asap cair, \%).
Data yang diperoleh dianalisis menggunakan analisis regresi linear sederhana. Analisis regresi antara variabel $\mathrm{X}$ dan $\mathrm{Y}$ dilakukan pada taraf nyata $1 \%$ atau $5 \%$. Analisis regresi dilakukan menggunakan program Statistical Package for Social Science (SPSS) versi 20.

\section{HASIL DAN PEMBAHASAN}

Mortalitas Rayap. Mortalitas rayap akibat perlakuan asap cair pada berbagai suhu dan konsentrasi selama 21 hari terlihat pada Gambar 1-3. Hasil analisis menunjukkan bahwa perlakuan konsentrasi asap cair dan suhu pirolisis $\left(350{ }^{\circ} \mathrm{C}, 400{ }^{\circ} \mathrm{C}\right.$, dan $\left.450{ }^{\circ} \mathrm{C}\right)$ berpengaruh nyata terhadap mortalitas rayap $(p<0,05)$. Persamaan regresi sederhana dan koefisien determinasi perlakuan konsentrasi asap cair terhadap mortalitas rayap pada suhu pirolisis asap cair $350{ }^{\circ} \mathrm{C}, 400{ }^{\circ} \mathrm{C}$, dan $450{ }^{\circ} \mathrm{C}$ berturut-turut adalah $\mathrm{Y}=31,4+11,76 \mathrm{X},\left(\mathrm{r}^{2}=\right.$ $0,60), \mathrm{Y}=30+11,86 \mathrm{X}\left(\mathrm{r}^{2}=0,59\right)$, dan $\mathrm{Y}=26,66+7,6 \mathrm{X}$ $\left(\mathrm{r}^{2}=0,429\right)$. Hal ini menunjukkan bahwa makin tinggi konsentrasi asap cair makin tinggi mortalitas rayap. Hal ini sejalan dengan makin tinggi konsentrasi asap cair makin tinggi kadar komponen dalam asap cair yang berfungsi sebagai antirayap. Yatagai et al. (2002) menyatakan bahwa konsentrasi asap cair yang tinggi mengakibatkan kematian rayap meningkat karena kemampuan bahan aktif dala asap cair khususnya asam asetat juga semakin banyak. Sejalan dengan hasil penelitian tersebut, mortalitas rayap tertinggi diperoleh pada konsentrasi $15 \%$.

Hubungan antara konsentrasi asap cair terhadap mortalitas rayap pada suhu $450{ }^{\circ} \mathrm{C}$ mempunyai nilai terkecil dibandingkan nilai mortalitas rayap dengan suhu $350{ }^{\circ} \mathrm{C}$ dan $400{ }^{\circ} \mathrm{C}$. Hal ini menunjukkan bahwa suhu pirolisis berpengaruh terhadap kadar komponen dalam asap cair terutama kadar fenol. Oramahi \& Yoshimura (2013) mengungkapkan bahwa kadar fenol total asap cair pada suhu pirolisis $350{ }^{\circ} \mathrm{C}, 400{ }^{\circ} \mathrm{C}$, dan $450{ }^{\circ} \mathrm{C}$ berturut-turut sebesar $5,22 \%, 5,89 \%$, dan $5,15 \%$. Penelitian tersebut hanya menganalisis kadar fenol total belum sampai menganalisis turunan fenol pada suhu yang berbeda.

Heo et al. (2011) mengungkapkan bahwa ada kecendrungan perubahan komponen penyusun asap cair dengan adanya peningkatan suhu pirolisis. Komponen asam asetat, asam benzoat fenol, $2 \& 3$-metilfenol, dan 1,2-benzedediol meningkat seiring dengan kenaikan suhu pirolisis sampai suhu $550{ }^{\circ} \mathrm{C}$. Penelitian tersebut menggunakan serbuk kayu (mebel) sebagai bahan baku untuk produksi asap cair pada suhu pirolisis $400{ }^{\circ} \mathrm{C}, 450$ ${ }^{\circ} \mathrm{C}, 500{ }^{\circ} \mathrm{C}$, dan $550{ }^{\circ} \mathrm{C}$. 


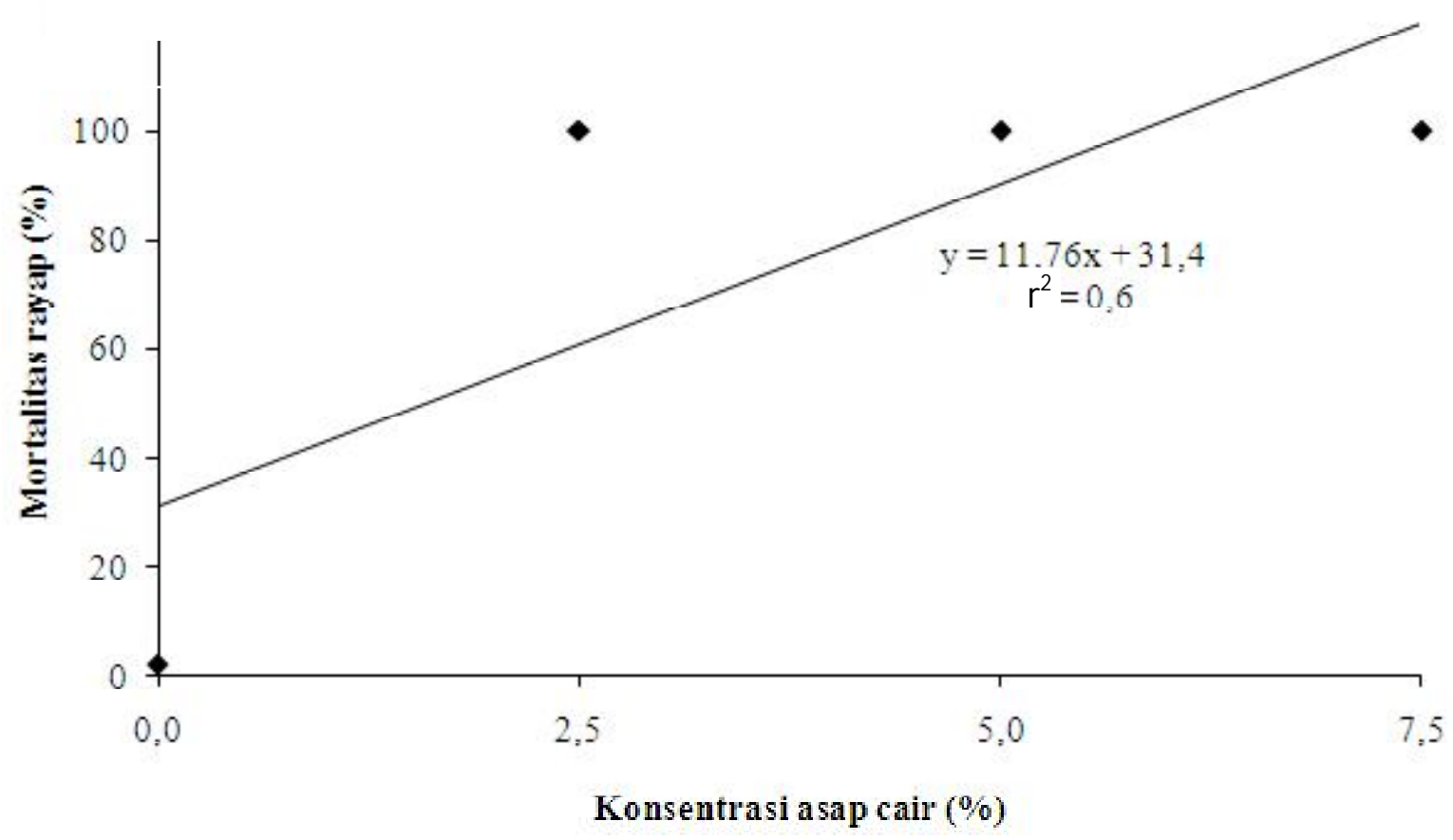

Gambar 1. Hubungan antara konsentrasi asap cair (\%) suhu pada pirolisis $350^{\circ} \mathrm{C}$ dan mortalitas rayap $C$. curvignathus.

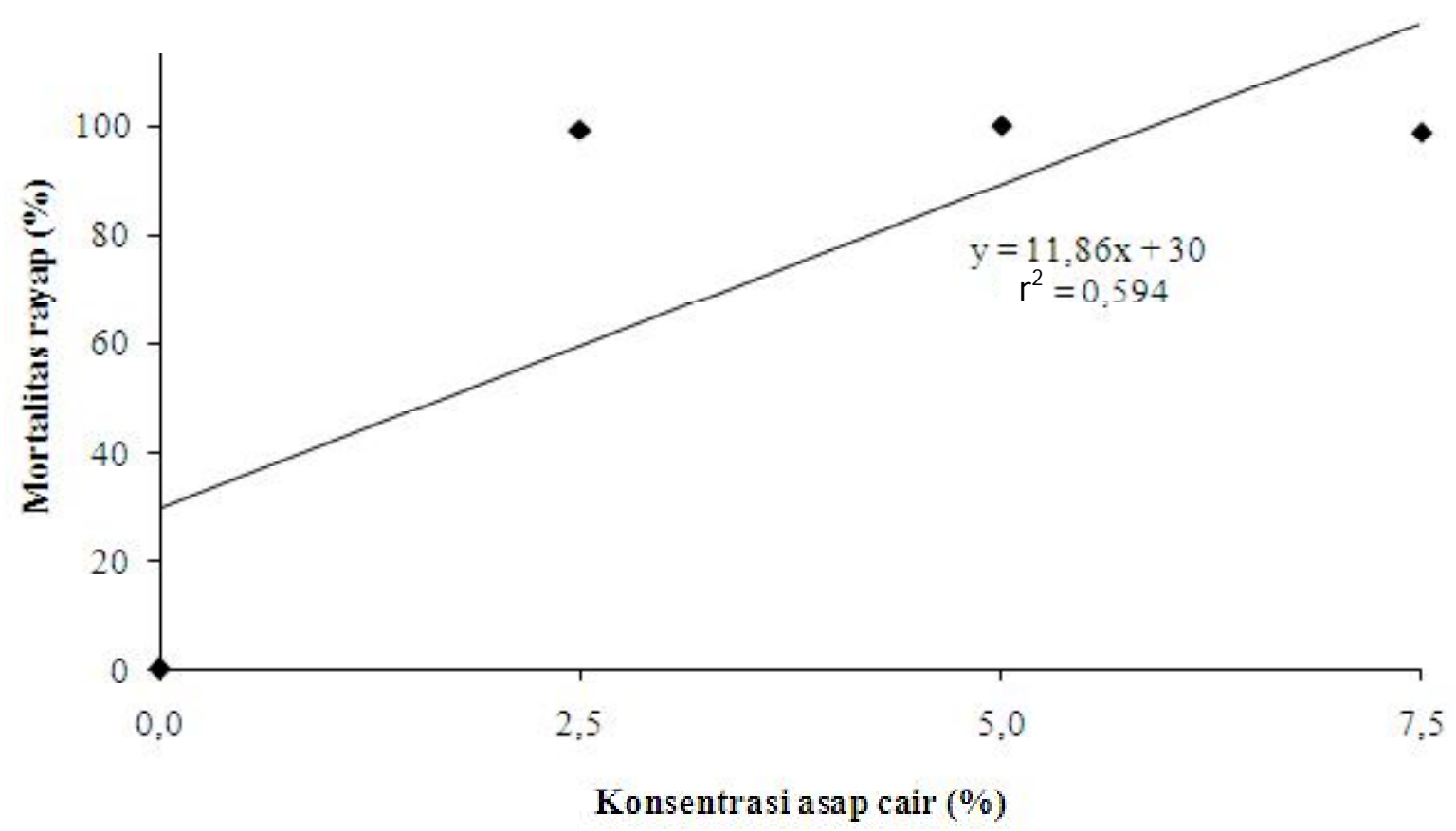

Gambar 2. Hubungan antara konsentrasi asap cair (\%) pada suhu pirolisis $400^{\circ} \mathrm{C}$ dan mortalitas rayap $C$. curvignathus. 


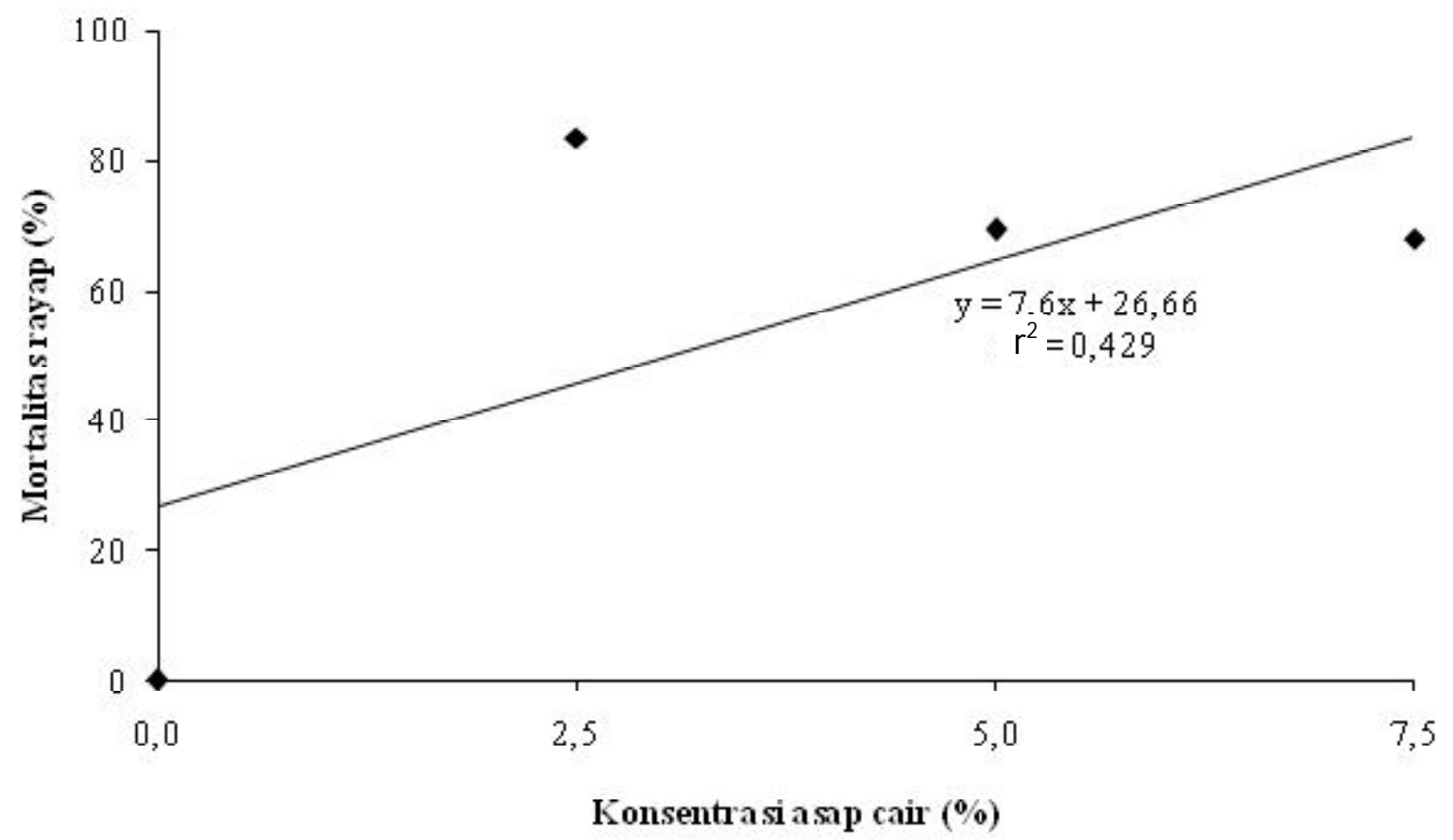

Gambar 3. Hubungan antara konsentrasi asap cair (\%) pada suhu pirolisis $450^{\circ} \mathrm{C}$ dan mortalitas rayap $C$. curvignathus.

Perbedaan kemampuan sifat antirayap asam cair sangat dipengaruhi oleh konsentrasi dan komponen penyusun asap cair. Hal ini sejalan dengan hasil penelitian Witisiri (2011) yang melaporkan bahwa asap cair dari tempurung kelapa mempunyai sifat antirayap yang tinggi terhadap Odontotermes sp. pada konsentrasi 1:50 (asap cair : air steril, v/v). Kartal et al. (2004) melaporkan bahwa asap cair hasil pirolisis campuran kayu sugi (Cryptomeria japonica D. Don) dan akasia (Acacia mangium Willd) tidak berpengaruh nyata terhadap mortalitas rayap Coptotermes formosanus yang diberi perlakuan asap cair dan kontrol. Namun persentase penurunan bobot lebih kecil pada sampel kontrol daripada sampel yang diberi perlakuan asap cair. Lebih lanjut dijelaskan bahwa konsentrasi asap cair merupakan faktor penting sebagai bahan antirayap.

Sementara itu, Yatagai et al. (2002) menemukan tiga jenis asap cair yang diperoleh dari tiga jenis kayu yang berbeda mempunyai aktivitas terhadap $R$. speratus. Lebih lanjut dijelaskan bahwa komponen yang berperan sebagai antirayap adalah asam asetat. Oramahi \& Yoshimura (2013) melaporkan bahwa komponen asam pada asap cair yang diperoleh dari hasil pirolisis kayu laban pada suhu pirolisis $350{ }^{\circ} \mathrm{C}, 400{ }^{\circ} \mathrm{C}$, dan $450{ }^{\circ} \mathrm{C}$ berturut-turut sebesar 2,13\%, 2,10\%, dan 3,27\%.

Bedmutha et al. (2011) memperoleh komponen penyusun asap cair dari coffee grounds terdiri atas 2- siklopenten-1-on, 2-metilfenol, 3-metilfenol, 4-metilfenol, 2,6-metilfenol, 2,3-metilfenol, 3,3-metilfenol, 2,4metilfenol, 3-etilfenol, 3,5-dimetilfenol, 2,3-dimetilfenol, 2-etil-6-metilfenol, indolizin, dan asam asetat. Sementara itu, Oramahi \& Diba (2013) mengungkapkan bahwa komponen penyusun asap cair dari kulit buah durian antara lain asam asetat, metilalkohol, 2-propanon,1hidroksi, 2-propanon, turunan karbonil dan turunan fenol.

Kehilangan Bobot Kertas Saring. Kehilangan bobot kertas saring akibat perlakuan asap cair terhadap $C$. curvignathus pada berbagai suhu dan konsentrasi terlihat pada Gambar 4-6. Hasil analisis menunjukkan bahwa perlakuan konsentrasi asap cair dan suhu pirolisis $\left(350{ }^{\circ} \mathrm{C}, 400{ }^{\circ} \mathrm{C}\right.$, dan $450{ }^{\circ} \mathrm{C}$ ) berpengaruh nyata terhadap kehilangan bobot kertas saring $(p<0,05)$. Persamaan regresi sederhana dan koefisien diterminasi perlakuan konsentrasi asap cair terhadap kehilangan bobot kertas saring pada suhu pirolisis asap cair $350^{\circ} \mathrm{C}$, $400{ }^{\circ} \mathrm{C}$, dan $450{ }^{\circ} \mathrm{C}$ berturut-turut adalah $\mathrm{Y}=85,12$ $3,188 \mathrm{X}\left(\mathrm{r}^{2}=0,723\right), \mathrm{Y}=88,06-3,435 \mathrm{X}+\left(\mathrm{r}^{2}=0,953\right)$ dan $\mathrm{Y}=91,56-3,867 \mathrm{X}\left(\mathrm{r}^{2}=0,886\right)$.

Makin tinggi konsentrasi asap cair makin rendah persentase penurunan bobot kertas saring. Hal ini berhubungan dengan aktivitas makan rayap dalam mengkomsumsi kertas saring. Hubungan suhu pirolisis terhadap penurunan bobot kertas saring dipengaruhi oleh 


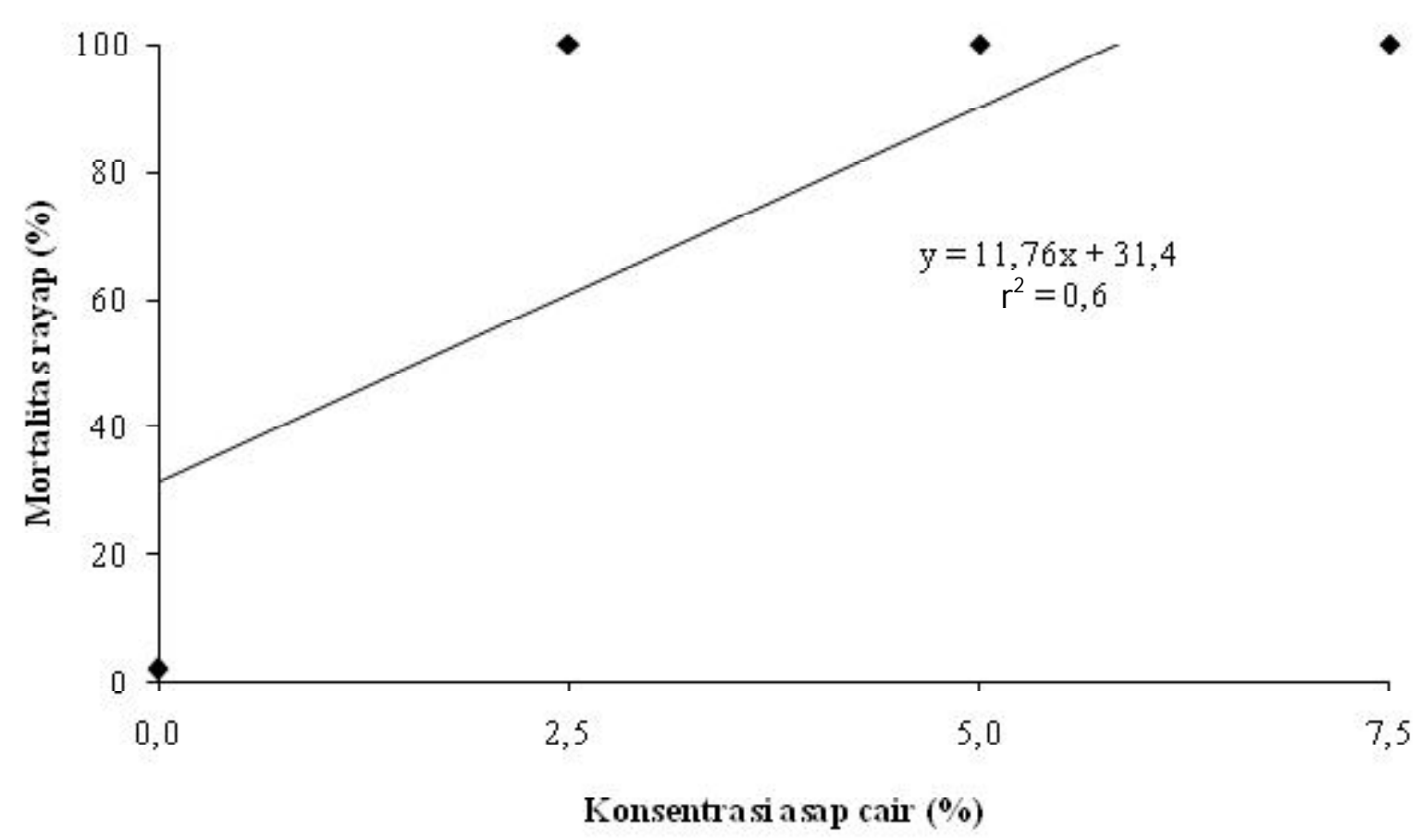

Gambar 4. Hubungan antara konsentrasi asap cair (\%) pada suhu pirolisis $350^{\circ} \mathrm{C}$ dan kehilangan bobot kertas saring.

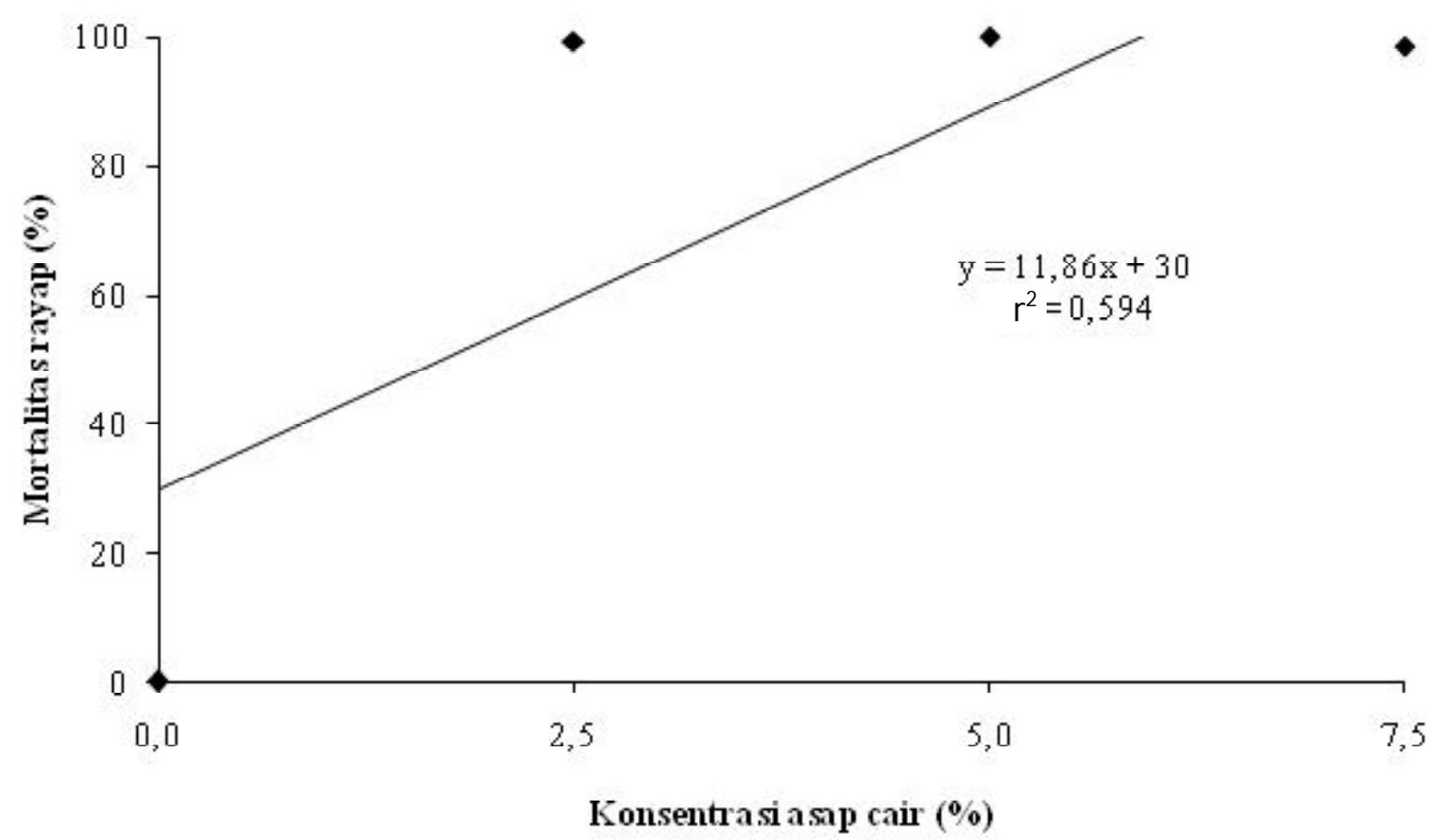

Gambar 5. Hubungan antara konsentrasi asap cair (\%) pada suhu pirolisis $400^{\circ} \mathrm{C}$ dan kehilangan bobot kertas saring. 


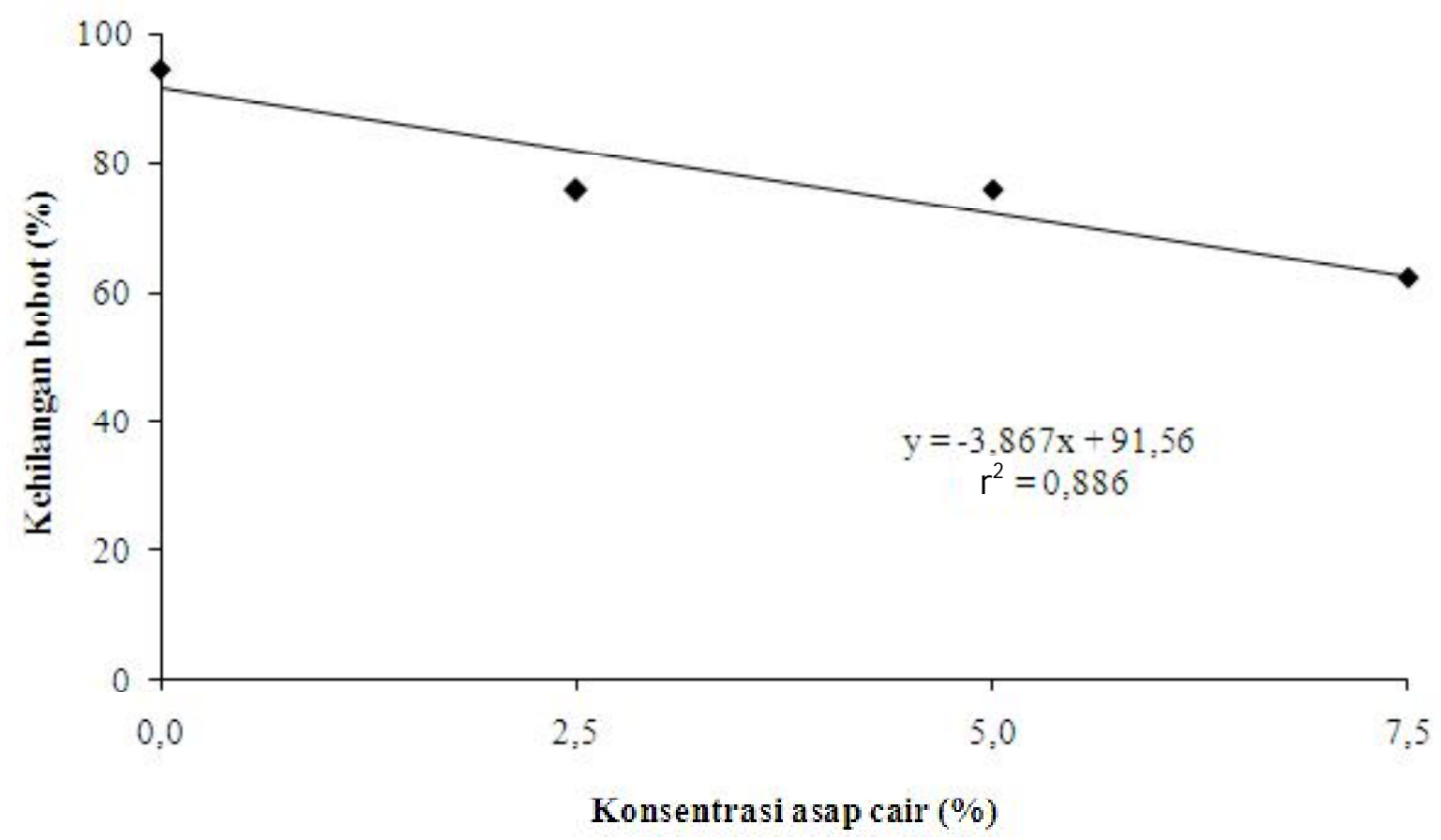

Gambar 6. Hubungan antara konsentrasi asap cair (\%) pada suhu pirolisis $450^{\circ} \mathrm{C}$ dan kehilangan bobot kertas saring.

mortalitas rayap karena rayap yang mampu bertahan hidup tetap mengkonsumsi kertas saring yang menyebabkan penurunan bobot makin tinggi. Gambar 3-6 menunjukkan bahwa perlakuan konsentrasi asap cair $(2,5 \%-7,5 \%)$ tehadap rayap C. curvignathus menyebabkan penurunan bobot kertas saring sebesar 62,2\%-75,9\%. Oramahi \& Yoshimura (2013) mengungkapkan bahwa aplikasi asap cair dari kayu laban pada konsentrasi 1\%-5\% terhadap rayap Reticulitermes speratus menyebabkan penurunan berat kertas saring sebesar 6,7\%-23,7\%. Perbedaan persentase penurunan kertas saring antara penelitian ini dengan penelitian Oramahi \& Yoshimura (2013) disebabkan perbedaan jenis rayap yang digunakan sehingga terjadi perbedaan konsumsi makanan.

Menurut Yoshimura et al. (2003), konsumsi makanan terhadap kayu Pinus densiflora antara rayap $C$. formosanus dan $R$. speratus masing-masing sebesar 0,0961 mg/rayap/hari dan 0,0737 mg/rayap/hari. Hal ini disebabkan oleh perbedaan ukuran rayap $C$. formosanus dan $R$. speratus (Oramahi \& Yoshimura, 2013). Ukuran rayap C. formosanus lebih besar daripada $R$. speratus. Penelitian ini menggunakan rayap C. curvignathus yang mempunyai ukuran hampir sama dengan rayap C. formosanus.
Penelitian lebih lanjut perlu dilakukan aplikasi asap cair dari kayu laban untuk pengawet kayu maupun pengendalian rayap pada tanaman perkebunan dan kehutanan. Pemanfaatan asap cair untuk pengawet kayu perlu dicari keefektifannya antara metode pencelupan, perendaman atau pelaburan. Begitu juga bila pemanfaatan asap cair untuk pengendalian rayap pada tanaman perkebunan dan kehutanan, perlu dilakukan kajian keefektifan antara metode penyemprotan dan penyuntikan. Selain itu perlu juga kajian keamanan asap cair yang diduga mengandung senyawa yang toksik terhadap hewan peliharaan atau manusia.

\section{SIMPULAN}

Asap cair hasil pirolisis kayu laban mempunyai aktivitas sebagai bahan antirayap terhadap $C$. curvignathus secara in vitro. Konsentrasi asap cair berpengaruh nyata terhadap mortalitas rayap dan kehilangan bobot kertas saring $(p<0,05)$. Makin tinggi konsentrasi asap cair makin tinggi mortalitas rayap $C$. curvignathus dan makin rendah persentase penurunan bobot kertas saring. 


\section{SANWACANA}

Penulis mengucapkan terima kasih kepada Universitas Tanjungpura Pontianak yang telah memberikan dana penelitian melalui DIPA Universitas Tanungpura Nomor: 754a/UN22.7/PL/2012, tanggal 4 September 2012. Penulis juga mengucapkan terima kasih kepada Hendra Prawira yang telah membantu dalam penelitian ini.

\section{DAFTAR PUSTAKA}

Bedmutha R, Booker CJ, Ferrante L, Briens C, Berruti F, Yeung KKC, Scott IM, \& Conn KL. 2011. Insecticidal and bactericidal characteristics of the bio-oil from the fast pyrolysis of coffee grounds. J. Anal. Appl. Pyrol. 90(2): 224-231.

Calderon RA \& Constantino R. 2007. A survey of the termite fauna (Isoptera) of an eucalypt plantation in Central Brazil. Neotrop. Entomol. 36(3): 391395.

Darmadji P. 1997. Aktivitas antibakteri asap cair yang diproduksi dari bermacam-macam limbah pertanian. Agritech 6(4): 19-22.

Darmadji P, Oramahi HA \& Haryadi. 2000. Optimasi produksi dan sifat fungsional asap cair kayu karet. Agritecth 20(3): 147-155.

Ganapaty S, Thomas PS, Fotso S, \& Laatsch H. 2004. Antitermitic quinones from Diospyros sylvatica. Phytochemistry 65(9): 1265-1271.

Ghaly A \& Edwards S. 2011. Termite damage to buildings: nature of attacks and preventive construction methods. Am. J. Eng.Appl. Sci. 4: 187-200.

Girard JP. 1992. Technology of Meat and Meat Product Smoking. Ellis Harwood, New York.

Heo HS, Park HJ, Park YK, Ryu C, Suh DJ, Suh YW, Yim JH \& Kim SS. 2011. Bio-oil production from fast pyrolysis of waste furniture sawdust in a fluidized bed. Bioresour. Technol 101(1): S91S96.

Jasmi AH \& Ahmad AH. 2011. Termite incidence on an Araucaria plantation forest in Teluk Bahang, Penang. Insects 2(4): 469-474.

Jones DT \& Prasetyo AH. 2002. A Survey of the termites (Insecta: Isoptera) of Tabalong District, South Kalimantan, Indonesia. The Raffles Bulletin of Zoology 50(1): 117-128.
Kang HY, Matsushima N, Sameshima K \& Takamura N. 1990. Termite resistance tests of hardwoods of Kochi growth 1: the strong termiticidal activity of kagonoki (Litsea coreana Leveille). Mokuzai Gakkaishi 36(1): 78-84.

Karseno, Darmadji P \& Kapti R. 2001. Daya hambat asap cair kayu karet terhadap bakteri pengkontaminan lateks dan ribbed smoke sheet. Agritech 21(1): 10-15.

Kartal SN, Imamura Y, Tsuchiya F, \& Ohsato K. 2004. Evaluation of fungicidal and termiticidal activities of hydrolysates from biomass slurry fuel production from wood. Bioresour. Technol. 95: 41-47.

Lee SH, H'ng PS, Lee AN, Sajap AS, Tey BT \& Salmiah U. 2010. Production of pyroligneous acid from lignocellulosic biomass and their effectiveness against biological attacks. J. Appl. Sci. 10(20): 2440-2446.

Lee SH, H'ng PS, Cow MJ, Sajap AS, Tey BT, Salmiah U, \& Sun YL. 2011. Effectiveness of pyroligeneous acid from vapour released in charcoal industry against biological attacks under laboratory condition. J. Appl. Sci. 11(24): 38483853.

Maga JA. 1988. Smoke in Food Processing, CRC Press, Boca Raton.

Meyer JR. 2005. Isoptera. Department of Entomology, NC State University. Raleigh. http:// www.cals.ncsu.edu/course/ent425/compendium/ termites.html. (Accessed 10 Januari, 2012).

Mohan D, Shi J, Nicholas DD, Pittman Jr CU, Steele PH, \& Cooper JE. 2008. Fungicidal values of bio-oils and their lignin-rich fractions obtained from wood/bark fast pyrolysis. Chemosphere 71(3): 456-465.

Montgomery DC. 1991. Design and Analysis of Experiments. Third Edition. John Wiley and Sons, New York.

Nandika D, Rismayadi Y \& Diba F. 2003. Rayap: Biologi dan Pengendaliannya. Muhammadiyah University Press, Surakarta.

Ohmura W, Doi S, Aoyama M, \& Ohara S. 2000. Antifeedant activity of flavonoids and related compounds against the subterranean termite Coptotermes formosanus Shiraki. J. Wood Sci. 46: 149-153. 
Okutucu C, Duman G, Ucar S, Yasa I, \& Yanik J. 2011. Production of fungicidal oil and activated carbon from pistachio shell. J. Anal. Appl. Pyrol. 91: 140-146.

Oramahi HA \& Diba F. 2013. Maximizing the production of liquid smoke from bark of durio by studying its potential compounds. Procedia Environ. Sci. 17: 60-69.

Oramahi HA \& Yoshimura T. 2013. Antifungal and antitermitic activities of wood vinegar from Vitex pubescens Vahl. J. Wood Sci. 59: 344-350

Owoyemi JM, Joshua Kayode K, \& Olaniran SO. 2011. Evaluation of the resistance of Gmelina arborea wood treated with creosote oil and liquid cashew nut shell to subterranean termites' attack. Pro Ligno 7: 3-12.

Tranggono, Suhardi, Setiadji B, Darmadji P, Supranto, \& Sudarmanto. 1996. Identifikasi asap cair dari berbagai jenis kayu dan tempurung kelapa. Jurnal Ilmu dan Teknologi Pangan 1: 15-24.
Verma M, Sharma S, \& Prasad R. 2009. Biological alternatives for termite control: A review. Int. Biodeterior. Biodegrad. 63(8): 959-972.

Witisiri S. 2011. Production of wood vinegars from coconut shells and additional materials for control of termite workers, Odontotermes sp. and striped mealy bugs, Ferrisia virgata. Songklanakarin J. Sci. Technol 33: 349-354.

Yatagai M, Nishimoto M, Ohira KHT, \& Shibata A. 2002. Termiticidal activity of wood vinegar, its components and their homologues. J. Wood Sci. 48(2):338-342.

Yoshimura T, Imamura Y, Takahashi M. 2003. Attacks on foam insulation materials by Coptotermes formosanus Shiraki and Reticulitermes speratus (Kolbe). Japanese J. Environ. Entomol. Zool. 14: 213-222. 